
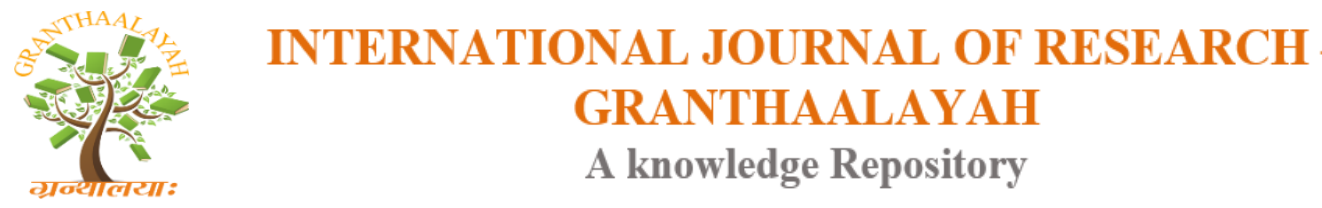

Science

\title{
DERMATOLOGICAL MANIFESTATIONS DUE TO TOXINS WITH SPECIAL REFERENCE TO VISHA
}

\author{
Gopendra Chandra Kamal ${ }^{* 1}$, Ashwini Kumar S Bharati ${ }^{2}$, Chaitra H Gururaj ${ }^{3}$ \\ ${ }^{* 1}$ PG Scholar, Department of Agada Tantra, SDM College of Ayurveda and Hospital, Hassan, \\ Karnataka, India \\ ${ }^{2}$ Professor, Department of Agada Tantra, SDM College of Ayurveda and Hospital, Hassan, \\ Karnataka, India \\ ${ }^{3}$ Associate Professor, Department of Agada Tantra, SDM College of Ayurveda and Hospital,
} Hassan, Karnataka, India

\begin{abstract}
Background: Ayurveda treatises are collection of vast knowledge regarding medical and environmental aspects. It has a separate branch called Agada Tantra which deals with the toxicological aspects. We aim to evaluate this knowledge regarding dermatological manifestation due to Visha (toxins) vis-à-vis contemporary knowledge.

Method: The references available regarding the different types of poison and their dermatolgical manifestations in classical text were studied and compared with the available information in the contemporary medical literatures.

Results: The term Visha and its types incorporates all kind of toxins. Initially, exposure to sthavara visha manifests into contact dermatitis and jangama visha manifests into contact urticaria. Dooshivisha and gara visha can be understood in terms with pesticide exposure, cosmetic toxicity, occupational exposures etc.

Conclusion: The dematological manifestations play clear cut role in diagnosis and prognosis. The abundant reference in Ayurveda literatures regarding same is useful at exploring the causative factors through toxicological aspect.

Keywords: Agada; Dermatology; Skin; Toxicology; Toxin; Visha.

Cite This Article: Gopendra Chandra Kamal, Ashwini Kumar S Bharati, and Chaitra H Gururaj. (2018). "DERMATOLOGICAL MANIFESTATIONS DUE TO TOXINS WITH SPECIAL REFERENCE TO VISHA." International Journal of Research - Granthaalayah, 6(4), 61-71. https://doi.org/10.29121/granthaalayah.v6.i4.2018.1476.
\end{abstract}

\section{Introduction}

The skin is the largest organ and acts as barrier between the body and the environment. It is multilayered, layers of living cells lie underneath the layer of dead cells. Toxin is a naturally (plant, animal and micro-organism) produced chemical that alters the normal function of another 
organism. However in alternative medicine and by the lifestyle journalists, the term "toxin" is used to refer to any substance alleged to cause ill health. This could include the sthavara visha (poison of plant origin), jangama visha (poison of animal origin), dhatu visha (poisonous metals and minerals), dooshivisha (cumulative poison), gara visha (artificial poison) etc mentioned in Ayurveda treatises. Ayurveda has a separate branch called Agada Tantra which deals with these toxicological aspects including the dermatological manifestation due to visha [1].

When the toxin reaches the Rakta dhatu and living cells of skin, the response is inflammation. Whenever visha comes in contact with body, either externally or internally, skin manifestations are seen [2]. There are twenty-four types of skin manifestations mentioned under the heading of Rakta Pradosaja vikara [3]. These diseases occur due to the vitiation of rakta dhatu, i.e the blood and its components. These are Kustha (skin disease), Visarpa (eryseplas), Pidika (furuncles and carbuncles), Raktapitta (bleeding from different parts of the body), Raktapradara (menorrhagia), Guda-medhrapaka (suppuration in perineum region), Pliha roga (spleen disorders), Vidradhi (abscess), Kamla (jaundice), Nilika (blackish spots), Vyanga (freckles) Piplu (portwine mark), Tilakalaka (non-elevated black mole), Dadru (ringworm) Charmadala (mole), Switra (vitiligo), Pama, (papules), kotha (urticarial rash), Nyachha (mole) Indrlupta (alopecia), Vatashonita, Arsha (haemorrhoids), Arbuda (tumour), Raktamandala (reddish lesions). If patches of kushta are hard and rough like stone, if there is numbness and unresponsive or if condition is chronic, then patient should be given agada yogas (formulations against toxins) internally and thereafter, pradeha (anointments) containing agada drugs applied [4].

\section{Chemical- skin interactions [5]}

Local effect- Exposure to chemicals can cause a problem at the point of contact. These effects are called direct effects. 1) Drying- some chemicals remove the natural oils from the skin, causing it to become very dry. The most frequent causes of dry skin are exposures to soaps, solvents, and moisture. 2) Irritation- some chemicals cause reddening, drying and cracking of the skin at the point of contact. These chemicals are known as irritants. Fiberglass, soaps, oils and solvents are examples. 3) Change in skin colour- A permanent change in skin colour may be due to certain chemical like tar, asphalt and disinfectants etc. 4) Corrosion- corrosive substance can cause severe damage to the skin like scarring, eg. acid and strong alkalis. 5) Acne- It may be caused by direct contact of the chemical like chlorine. 6) Skin cancer- many carcinogens are found at the work place. They may directly cause malignant tumors at site of contact.

Systemic effect- Chemicals may enter the body through skin and may damage specific organs like liver and kidney by solvents containing toluene and xylene. Toxins may enter the body through skin and may damage the nervous system, reproductive system and immune system. Several pesticides enter the body through skin and damage the nervous system and even causes death.

Sensitization effect- Chemical exposure may cause a person to become unusually sensitive to that chemical or group of chemical. Reaction may occur from exposure to small amount of that toxin. Once sensitized, the person will suffer allergic reaction to that chemical.

Impact of Chemical Exposure on Skin- Chemical exposures to the skin can cause temporary or permanent health damage. Temporary skin damage may occur from exposure to chemicals. For 
example, many workers may experience dry, red, cracked skin from contact with water, soaps, gasoline, and certain types of solvents. These health problems usually heal quickly when the skin is no longer in contact with the substance. Permanent skin damage may result if the skin is exposed to a chemical that is known to have a severe impact. For example, a chemical burn, as shown, may leave a permanent scar. Exposure to certain chemicals can result in permanent loss of skin color.

\section{Material and Methods}

The references regarding the venomous bites and stings, clinical skin manifestation due to poisons of plant and mineral origins, medicines, pesticides etc. will be collected from the Ayurveda classical treatises and the same will be presented along with the outpatient observations, case report, published article and documents.

\subsection{Skin Manifestaions Due to Sthavara Visha}

\section{Strong acids [6]}

Strong acids may cause corrosion and burning of the tissues and charring \& blackening of the skin. Tissue may get dehydrated with no blisters in case of acid. Scar remains permanently.

\section{Strong alkali [7]}

Strong alkalis act as corrosive poison. On contact with skin may cause blister and brownish discolouration. eg. Sodium hydroxide

\section{Non- metallic irritant poison [8]}

Phosphorus may cause subcutaneous haemorrhages, $2^{\text {nd }} \& 3^{\text {rd }}$ degree with blisters and tissue necrosis. There is rapid penetration and delayed wound healing. Bromine may cause chronic ulcer on external contact. Chlorine causes irritation of skin in swimmer.

\section{Metallic irritant poison [9]}

Arsenic poisoning may lead to alopecia, hyperkeratosis, aldrich- mess line on nails and raindrop pigmentation. Large population based studies from West Bengal in India showed a relationship between arsenic concentration in tube well water and hyperpigmentation and keratosis. Arsenic may cause a basal cell carcinoma in a non-melanin pigmented skin [10] Mercury poisoning has skin manifestations like acrodynia or pink disease, itching, acral rashes and desquamation of palms and soles. Lead poisoning has dermatological symptoms like pallor face and alopecia. Copper poisoning may cause contact dermatitis and bluish-greenish discolouration of skin and gums.

\section{Irritant plant poison [11]}

Jayapala (Croton tigilum) cause burning sensation, redness and vesication. Gunja (Abrus precatorius) may produce symptoms which resemble like viper snake bite. Inflammation, oedema, 
oozing, and necrosis. Ergot (Claviceps perpura) produces dry gangrene without swelling and ulceration. Arka (Calotropis procera) causes redness with blisters and excoriation later. Bhallataka (semicarpos anacarium) produces bruises and blisters.

\subsection{Skin Manifestations Due to Jangama Visha}

\section{Darvikara Sarpa Visha (Cobra Bite)}

Skin manifeststions are blackish discolouration around bite mark, sensatation of crawaling of insect over skin in $1^{\text {st }}$ vega (stage of symptoms), wound formation in $2^{\text {nd }}$ vega and suppuration in $3^{\text {rd }}$ vega [12]. Local symptoms starts within 6-8 minutes. Small reddish wheal develops which later turns purple- blackish with tenderness and burning sensation. Sloughing occurs in 1-2 days [13].

\section{Mandali Visha (Viper Snake Bite)}

It presents with yellowish discharge and yellowish discolouration of blood in $1^{\text {st }}$ Vega, yellowish discoloration of skin, burning sensation and swelling over skin in $2^{\text {nd }}$ Vega and suppuration of the tissue in $3^{\text {rd }}$ Vega [14]. Pain and oozing, local necrosis, gangrene, serous and serangious blisters and petechial hemorrhage are the major skin manifestation in viper bites [15].

\section{Vrischika (Scorpion Sting)}

It presents with severe burning sensation, acute, throbbing and pricking pain with blackish discoloration [16]. Paraesthesia is common feature in scorpion sting [17].

\section{Loot Visha (Spider Sting)}

Lesions like ringworm, white, black, reddish, yellowish, soft and elevated lesion which is blackish at the centre and thread like at the periphery. These lesions are fast spreading and painful and burning. Suppuration is formed and new lesion develops to whichever part of the body comes in contact with the existing lesion [18].

\section{Makshika (Bee Sting)}

Bee sting presents with severe burning sensation, itching and pain. Fast spreading, blackish discolouration, burning sensation and elevated lesion [19].

\section{Kanava (wasp)}

Wasp stings are fast spreading with sever swelling and pain. Skin tissues may fall off [20].

\section{Alarka Visha (Rabid Bite)}

Itching, pain, discolouration, numbness, suppuration, swelling and shrinkage, tearing pain, blisters, nodular lesions are found at the bite mark over the period [21]. 


\section{Moosika Visha (Rat)}

Wherever the toxin i.e. semen from rats touches, new lesions are formed. Pallor discolouration, nodular swelling and suppurative lesions, horripilation, chronic ulcer and thick, slimy discharge from the wound [22].

\subsection{Doosivisha}

Dooshivisha is a form of toxin (animal origin, plant origin, artificial poison) that has not been completely eliminated or neutralised due to various reasons, remains in the body for some time and eventually gets manifested in the form of some disease [23]. Dooshivisha vitiates the rakta and hence manifests symptoms like aruh, kitibha and kotha [24]. Even venomous bite if not treated completely can act as dooshivisha. Cases of non-healing ulcer with known history of snake bite upto 20 years back have been reported in outpatient departments. For contemporary relevance, several agents can be considered as dooshivisha. Such can be categorized into animate poison, inanimate poison and artificial poison. Inanimate poisons include cumulative toxicity of herbs (phytotoxins, toxa-albumins), chronic exposure to metal \& mineral (dyes, paints etc.) Animate poison may be considered as rat bite, keeta, loota visha etc. Artificial poison include agriculture pesticides and fertilizers, medicinal preparations, alcoholism, incompatible diet. Skin manifestations like Vaivarnya (vitiated body complexion), kustha (skin diseases), mandal (cicular skin lesions), kotha (skin rashes), aruh (eruptions on skin) are observed on exposure to above said dooshivisha [25].

Cosmetic Toxicity is one of the major cause of skin problems. Cosmetic products conatins various chemical agents which may not be suitable to every individual and and may also end up having adverse reaction over prolonged use. Lotions contain Propylene glycol which may cause contact dermatitis and retinyl palmitate which has potential to change skin DNA, produce free radical and increase risk of cancer. Sunscreen lotions contain cinnamate and salicylate which are known to cause skin rash. Lipstick colour are from coal tar dyes which have every potential to cause skin irritation, allergy and malignancy. Cleanser and body wash contain sodium and ammonium laurel sulphates which are skin irritants and probable carcinogens [26].

\subsection{Gara visha}

Toxin can be administered as Gara visha (artificial poison) by vitiation of food, drinks, tooth brush, anointing oil, comb, massaging powders or paste, bathing water unguents, garlands, dress, bed, armours, ornaments, footwear, nasal drops, eye salves etc. Abhyanga visha (massage with vitiated oil) may cause eruptions, excessive perspiration, ulceration and exudation. Similar symptoms are observed in bathing, decoctions of bath, unguents, bed, cloths when vitiated with toxins. Abhusana visha and avharana visha (jewellery and clothing vitiated with some toxins or even if the individual is allergic to the material) there is high chance of skin manifestations. Clothing and jewellery vitiated with toxins may cause burning sensatation. Paduka visha (footwears are vitiated with toxins) may cause swelling, eruptions and discharge. Pralepa (anointments), if vitiated with toxins may cause burning sensation in hands and also falling of nails. Abhyanga (oil massage) if done with toxic agents may cause eruptions, swelling, discharge etc. Even the comb if made of improper material or smeared with toxins may cause hairfall and eruptions over scalp. Similar symptoms 
are observed due to poisoned materials of bath on head, helmet, headwear, garlands. The use of mukhalepa (facial cream), if adultered with toxins may cause blackish discolouration, eruptions, severe sweating, exudation, ulceration and comedons formation. Vahana Visa (poisoned materials used for riding on animals) causes eruptions on rider's buttock, anus, penis and scrotum [27]. On contact with body, mutra, purisa etc. which contains toxins, dermatological symptoms like kandu, daha, kotha, aru, pidika, toda, vedna, kleda, srava, tvacha paka etc. manifests [28].

The condition diagnosed as porphyria cutanea tarda in adults begins with bullous lesions which progresses to ulceration and generally heals, leaving pigmented scars characterized by the presence of microcysts. In children, the initial lesions resemble comedones and milia. The outbreaks are often traced to the consumption of wheat as food, after it had been prepared for planting by treating it with a fungicide, hexachlorobenzene [29].

\subsection{Viruddha ahara}

Viruddha ahara (incompatible food items) also act as Gara or visha [30]. All types of Viruddha Ahara do not produce disease because body elements like Dushya and Dehabala (immunity) protect the body from the diseases. Viruddha Ahara specially disturbed the functions of Agni (metabolic energy) and Srotas (channels) [31]. The vitiated Jatharagni does not digest even the Laghu Ahara (food substance easy to digest), resulting in state of indigestion. The Viruddha ahara, adhyasana (eating without previous food being digested) and ajirnasana (indigestion state) together leads to formation of toxins in the gut which is termed as Amavisha [32]. Tridosha get provocated by this type of Amavisha. In general, food substances and activities (Vihara) which are similar in quality to body humors (doshas) and deleterious to the body elements (dhatus) vitiate the body channels (srotas). The vitiation results in Srotodushti i.e. malfunctioning of Srotas. The symptoms of Srotodushti are atipravritti (increased activity like excessive proliferation of cells), sanga (obstruction like pores blockage), siragranthi (thickening and new growth like keratosis) and vimargagaman (leaving its own path and entering other path like malignancy).

\subsection{Vishaja Vrana}

Human beings are prone to injury resulting in vrana (wound). Wound healing is a natural process but they often remain in inflammatory stages for too long because of the exotoxins and bacterial colonization. Complication of non-healing wounds are vast and patients are at risk of septicaemia, toxic shock syndrome and in some cases amputation. Histologically, these types of wounds are infiltrated by $\mathrm{T}$ cells causing cascade of tissue toxicity [33].

\subsection{Bacterial manifestations of skin}

Streptocooccal and staphylococcal bacteria produces alpha toxins (pyrogenic toxin super antigens and haemolysins). Impetigo, ecthyma, erysipelas, cellulitis, folliculitits, furuncle and carbuncle are some of the bacterial manifestations of skin. Impetigo is exudative plaques on erythematous base. Ecthyma is a deeper pyoderma, often a consequence of neglected impetigo. Erysipelas is superficial spreading pyoderma. Cellulitits is deeper spreading pyoderma. Often both erysipelas 
and cellulitits co-exists. Folliculitits is inflammation of the hair follicles. Furuncle and carbuncle are deep seated follicular and perifollicular boils. Carbuncle have multiple heads. Clostridium perfringens alpha toxin (necrotizing, hemolytic, collagenase, protease) causes gas gangrene [34].

\subsection{Fungal Manifestation of Skin}

Dermatophytes live in dead keratin and stratum corneum. Mycotoxins are the secondary metabolite that weakens the receiving host by causing inflammation. The fungus uses this as strategy to further proliferate [35].

\subsection{Common Skin Disease Due to Chemical Exposure}

The six common disease are contact dermatitis, contact urticarial, acne, hyperpigmentation, phototoxicity \& photo-allergy and skin cancer [36].

\subsubsection{Contact Dermatitis}

1) Irritant contact Dermatitis may be acute or chronic. Agents involved are detergents, solvents, abrasive dusts, alkalis, cutting oils. Chemicals directly injure the skin without involving the immunological pathway. It may result into acute exudative lesion (eg. strong irritant) or dry dermatitic lesion (weak irritant). Several case diagnosed in the outpatients as vicharchika (contact dermatitis) often have significant history of cement exposure common in construction labourers.

2) Allergic contact dermatitis may be acute eczema and chronic eczema. Immunological pathway is involved. Common allergens are: 1) Plants- Parthenium and ivy 2) Metal-nickel and chromate 3) Rubber- mercapto mix and thiuram mix 4) Medicine-neomycin and benzocaine 5) Fragrance, parabenes and formaldehyde. Several cases diagnosed as kitibha in Agada Tantra outpatient have found to have history of pesticide exposure. Parthenium induced dermatitits is also very commonly seen [37].

\subsubsection{Contact Urticarial}

It is an immediate transient skin swelling surrounded by areas of redness (wheal and-flare). Causative agents may be foods, preservatives, fragrances, plant and animal products, metals, rubber latex etc [38].

\subsubsection{Acne and Pigmentary Disorders}

Acne may be caused by exposure to petroleum and its derivatives, metal working, coal tar products and halogenated aromatic compounds. Hyperpigmentation may result from excessive exposure to sunlight, glass workers, welders, open field cooks, bakers and silversmiths [39].

\subsubsection{Photo-Toxicity}


Reactivity of the skin to the UV/ visible radiation is increased by chemical. Drug or its metabolite accumulates in the skin, absorbs light and undergoes photochemical reaction followed by a photobiological reaction resulting into local tissue damage, i.e. erythema, edema, blistering, hyperpigmentation and desquamation. The shorter wavelength (290-320 nm, UV-B) are responsible. It involves non-immunological pathway. Eg. coal tar, fluoroquinolones, phenothiazines, psoralen, sulfonamides, tetracycline, thiazides, amiodarone, sulfones etc. [40].

\subsubsection{Photo-Allergy}

Reactivity of the skin to the chemicals is increased by the light exposure. It involves the immunological pathway. Drugs or metabolite induces a cell-mediated response which on which on exposure to longer wavelengths (320-400 nm, UV-A) produces a popular or eczematous contact dermatitis. Eg. Benzocaine, halogenated phenols, p-aminobenzoic acid, pyridoxine hydrochloride, sandalwood oil, sulfonylureas, griseofulvin, chloroquine, chlorpromazine etc. [41].

\subsubsection{Drug Allergy and Iatrogenic Drug Injury}

Most mild reaction like skin rash subside immediately and do not require treatment. However, in case of anaphylactic shock or angioedema, treatment is required. Drugs frequently causing allergic reaction are penicillin, cephalosporins, sulfonamides, tetracyclines, quinolones, anti-tubercular drugs, phenothiazines, salicylates, carbamazepine, allopurinol, ACE inhibitors, methyldopa, hydralazine, local anaesthetics etc. [42].

Iatrogenic drug injury may be seen as acne due to corticosteroids, urticaria and exfolliative dermatitits due to penicillin and sulfonamides and fixed drug eruptions due to chemotherapeutic agents [43].

Stevens-Johnson syndrome (SJS) and toxic epidermal necrolysis (TEN) are rare but severe cutaneous drug reactions endangering patient's life. Commonly caused by antimicrobials, anti-epileptic drugs and non-steroidal anti-inflammatory agents (NSAIDs). Skin lesions precedes mucosal lesions in $50 \%$ of patients. Oral, conjunctiva and genital mucosa are involved. Reported cases of malignancy are non-Hodgkin's, Lymphoma, fibrillary astrocytoma, carcinoma breast, and carcinoma cervix [44].

\section{Discussion}

Scope of toxin is very broad, vague and controversial. While there is conflict to consider it as a biological product or chemical agent, the term "Visha" seems to include all the forms of toxins. The relationship between dermal uptake and health effects observed elsewhere (i.e. systemic effect) in the body is still poorly understood. And most of the case presented at outpatient and diagnosed are of the local effect of toxins. Venoms contain fibrinolysin, haemolysin, agglutinin, phospholipase, coagulase, histamines etc. as toxic principles responsible for the action on blood and inflammation manifested on skin. Most of the irritant plant poison contains toxa-albumins and 
alkaloids. The initial skin manifestations of the sthavara visha has features of contact dermatitis, while the initial skin manifestations of jangama visha have features of contact urticaria. Skin manifestations due to Dooshivisha and gara visha can be understood in view of the occupational exposure like pesticides, cosmetics, metals, rubber etc.

\section{Conclusion}

Skin acts as one of the principle target organ for any poisonous manifestation. It may either spread all over the body or only to the part which is exposed to the environment or toxin. Dermatological manifestation plays an important role in clear cut diagnosis of the poison. It is useful for knowing the prognosis of the disease depending upon the size, shape, colour, depth of tissue involved and the time since manifestation occured.

\section{References}

[1] Aravind, D, Kamal, G.C, Ballav, S, Bharati, A.K.S. CONCEPTUAL STUDY ON ANTI-TOXIC ACTION OF KSHARA AGADA: A REVIEW. Int J Res Ayurveda Pharm. 2017;8(1): 19-21.

[2] Vagbhata. Uttarasthana Chapter 35/9. In: Kunte, A.M, Navare, K.R.S, Vaidya, H.P (eds.) Astangahrdayam. Varanasi: Chaukhambha Orientalia; 2014. p. 903.

[3] Agnivesa. Sutrasthana chapter 28/11-12. In: Charaka, Dridhbala, Chakrapanidutta (eds.) Charaka Samhita with Ayurveda Dipika Commentary. Varanasi: Chaukhambha Orientalia; 2015. p. 179.

[4] Agnivesa. Chikitsasthana chapter 7/55. In: Charaka, Dridhbala, Chakrapanidutta (eds.) Charaka Samhita with Ayurveda Dipika Commentary. Varanasi: Chaukhambha Orientalia; 2015. p. 453.

[5] Cdcgov. Cdcgov. [Online]. Available from: https://www.cdc.gov/niosh/docs/2011-199/pdfs/2011199.pdf [Accessed 21 March 2018].

[6] Biswas, G. Review of Forensic Medicine and Toxicology. (3rd ed.). New Delhi: Jaypee Brothers Medical Publishers; 2015.

[7] Biswas, G. Review of Forensic Medicine and Toxicology. (3rd ed.). New Delhi: Jaypee Brothers Medical Publishers; 2015.

[8] Biswas, G. Review of Forensic Medicine and Toxicology. (3rd ed.). New Delhi: Jaypee Brothers Medical Publishers; 2015.

[9] Biswas, G. Review of Forensic Medicine and Toxicology. (3rd ed.). New Delhi: Jaypee Brothers Medical Publishers; 2015.

[10] Ratnaike RN. Acute and chronic arsenic toxicity. Postgraduate medical journal. 2003 Jul 1;79(933):391-6.

[11] Pillay, VV. Modern Medical Toxicology. (4 ${ }^{\text {th }}$ ed.). New Delhi: Jaypee Brothers Medical Publishers; 2013.

[12] Vagbhata. Uttarasthana Chapter 36/19. In: Kunte, A.M, Navare, K.R.S, Vaidya, H.P (eds.) Astangahrdayam. Varanasi: Chaukhambha Orientalia; 2014. p. 909.

[13] Pillay, VV. Modern Medical Toxicology. ( ${ }^{\text {th }}$ ed.). New Delhi: Jaypee Brothers Medical Publishers; 2013.

[14] Vagbhata. Uttarasthana Chapter 36/23. In: Kunte, A.M, Navare, K.R.S, Vaidya, H.P (eds.) Astangahrdayam. Varanasi: Chaukhambha Orientalia; 2014. p. 909.

[15] Review of Forensic Medicine and Toxicology. (3rd ed.). New Delhi: Jaypee Brothers Medical Publishers; 2015.

[16] Vagbhata. Uttarasthana Chapter 37/6. In: Kunte, A.M, Navare, K.R.S, Vaidya, H.P (eds.) Astangahrdayam. Varanasi: Chaukhambha Orientalia; 2014. p. 914.

[17] Biswas, G. Review of Forensic Medicine and Toxicology. (3rd ed.). New Delhi: Jaypee Brothers Medical Publishers; 2015. 
[18] Vagbhata. Uttarasthana Chapter 37/55-57. In: Kunte, A.M, Navare, K.R.S, Vaidya, H.P (eds.) Astangahrdayam. Varanasi: Chaukhambha Orientalia; 2014. p. 918.

[19] Agnivesa. Chikitsasthana chapter 23/158. In: Charaka, Dridhbala, Chakrapanidutta (eds.) Charaka Samhita with Ayurveda Dipika Commentary. Varanasi: Chaukhambha Orientalia; 2015. p. 578.

[20] Agnivesa. Chikitsasthana chapter 23/152. In: Charaka, Dridhbala, Chakrapanidutta (eds.) Charaka Samhita with Ayurveda Dipika Commentary. Varanasi: Chaukhambha Orientalia; 2015. p. 578.

[21] Vagbhata. Uttarasthana Chapter 38/12-13. In: Kunte, A.M, Navare, K.R.S, Vaidya, H.P (eds.) Astangahrdayam. Varanasi: Chaukhambha Orientalia; 2014. p. 921.

[22] Vagbhata. Uttarasthana Chapter 37/3-5. In: Kunte, A.M, Navare, K.R.S, Vaidya, H.P (eds.) Astangahrdayam. Varanasi: Chaukhambha Orientalia; 2014. p. 920.

[23] Kamal, G.C, Bharati, A.K.S. Chronic lead poisoning in children “. Ayurlog: NJRAS. 2017;5(Ayurkaushalya -special issue): 153-159.

[24] Agnivesa. Chikitsasthana chapter 23/31. In: Charaka, Dridhbala, Chakrapanidutta (eds.) Charaka Samhita with Ayurveda Dipika Commentary. Varanasi: Chaukhambha Orientalia; 2015. p. 573.

[25] Jangid SK, Jadhav DK. "AYURVEDIC MANAGEMENT OF CUMULATIVE TOXICITY (DUSHI VISHA)": A REVIEW.

[26] Usturage, R.R, Pawade, U.V, Supugade, V.V. CRITICAL REVIEW OF COSMETIC TOXICITY WSR DUSHI VISHA. IAMJ. [Online] 2015; 3(12): 2539-2546. Available from: http://iamj.in/search_results/?search=Dushi+Visha [Accessed 21 March 2018].

[27] Susruta. Kalpasthan 1/48-74. In: Dalhana, Trikamji, Y.A (eds.) Susruta Samhita with Nibandha sangraha commentary. Varanasi: Chaukhambha Orientalia; 2014. p. 562-563.

[28] Susruta. Kalpasthan 8/39. In: Dalhana, Trikamji, Y.A (eds.) Susruta Samhita with Nibandha sangraha commentary. Varanasi: Chaukhambha Orientalia; 2014. p. 588.

[29] Cam CA, Nigogosyan G. Acquired toxic porphyria cutanea tarda due to hexachlorobenzene: Report of 348 cases caused by this fungicide. Jama. 1963 Jan 12;183(2):88-91.

[30] Vagbhata. Uttarasthana Chapter 7/29. In: Kunte, A.M, Navare, K.R.S, Vaidya, H.P (eds.) Astangahrdayam. Varanasi: Chaukhambha Orientalia; 2014. p. 133.

[31] Singh S, Byadgi PS, Tripathi JS, Rai NP. Etiopathogenesis of Kushtha Roga WSR to Psoriasis. International Journal of Pharmaceutical and Phytopharmacological Research. 2017 Mar 22;4(5):264-8.

[32] Agnivesa. Vimanasthana chapter 2/12. In: Charaka, Dridhbala, Chakrapanidutta (eds.) Charaka Samhita with Ayurveda Dipika Commentary. Varanasi: Chaukhambha Orientalia; 2015. p. 239.

[33] Ballav, S, Bharati, A.S.K. VISHAJA VRANA: A LITERARY REVIEW. Int J Res Ayurveda Pharm 8 (Suppl 1), 2017. [Online] 2017;8(1): 22-24. Available from: http://www.ijrap.net/admin/php/uploads/1717_pdf.pdf [Accessed 21 March 2018].

[34] Khanna, N. Illustrated Synopsis of Dermatology and Sexually Transmitted Diseases. (4th ed.). Delhi: Elsevier; 2014.

[35] Khanna, N. Illustrated Synopsis of Dermatology and Sexually Transmitted Diseases. (4th ed.). Delhi: Elsevier; 2014.

[36] Whoint.Whoint. [Online]. Available from: http://www.who.int/ipcs/publications/ehc/ehc_242.pdf [Accessed 21 March 2018].

[37] Khanna, N. Illustrated Synopsis of Dermatology and Sexually Transmitted Diseases. (4th ed.). Delhi: Elsevier; 2014.

[38] Khanna, N. Illustrated Synopsis of Dermatology and Sexually Transmitted Diseases. (4th ed.). Delhi: Elsevier; 2014.

[39] Whoint. Whoint. [Online]. Available from: http://www.who.int/ipcs/publications/ehc/ehc_242.pdf [Accessed 21 March 2018].

[40] Tripathi, K.D. Essentials of medical Pharmacology. (6th ed.). New Delhi: Jaypee brothers Medical Publishers (P) ltd; 2010.

[41] Tripathi, K.D. Essentials of medical Pharmacology. (6th ed.). New Delhi: Jaypee brothers Medical Publishers (P) ltd; 2010. 
[42] Tripathi, K.D. Essentials of medical Pharmacology. (6th ed.). New Delhi: Jaypee brothers Medical Publishers (P) ltd; 2010.

[43] Mohan, H. Textbook of Pathology. (6th ed.). New Delhi: Jaypee brothers Medical Publishers (P) ltd; 2010.

[44] Patel TK, Barvaliya MJ, Sharma D, Tripathi C. A systematic review of the drug-induced StevensJohnson syndrome and toxic epidermal necrolysis in Indian population. Indian Journal of Dermatology, Venereology, and Leprology. 2013 May 1;79(3):389

*Corresponding author.

E-mail address: gopendra2014@gmail.com 